\title{
Assesment of IIHR mango harvester for drudgery reduction over coventional practice
}

\author{
P. Aparna, G. Prasad Babu and B.H. Chaithanya
}

Received: 08.08.2020; Revised: 24.10.2020; Accepted: 13.11.2020

See end of the paper for authors' affiliations

\section{P. Aparna}

Krishi Vigyan Kendra, Banavasi

(A.P.) India

Email : aparnakallam26@gmail. com
ABSTRACT : Mango the "King of fruits" is the most important fruit crop in India. Harvesting of the mangoes are done with different methods by Indian farmers like manual plucking, tree shaking or local harvesters which are manufactured by the farmers. The tree branches are shaken to speed up the harvesting, which results in post harvest losses due to the physical damage, stem end rot and sap bleeding in mangoes due to absence of pedicel. To overcome these local harvesting methods and to reduce to drudgery of the farmers Krishi Vigyan Kendra, Banavasi has introduced IIHR model for harvesting mangoes and conducted frontline demonstration in farmer's field. Harvesting efficiency of different harvesters was studied in comparison to manual plucking and local made harvester was compared with that of Indian Institute of Horticultural Research, Bangalore (IIHR) model. Among all the methods IIHR model is found to have higher efficiency as compared to the local b models.

KEY WORDS: Mango, Drudgery

- HOW TO CITE THIS PAPER : Aparna, P., Babu, G. Prasad and Chaithanya, B.H. (2020). Assesment of IIHR mango harvester for drudgery reduction over coventional practice. Asian J. Home Sci., 15 (2) : 273 275, DOI: 10.15740/HAS/AJHS/15.2/273-275. Copyright@ 2020: Hind Agri-Horticultural Society. 